\title{
Host Status of Selected Peach Rootstocks to Meloidogyne mayaguensis
}

Andrew P. Nyczepir ${ }^{1}$

U.S. Department of Agriculture, Agricultural Research Service, Southeastern

Fruit and Tree Nut Research Laboratory, 21 Dunbar Road, Byron, GA 31008

Janete A. Brito

Division of Plant Industry, P.O. Box 147100, Gainesville, FL 32614

\author{
Don W. Dickson \\ Entomology and Nematology Department, University of Florida, Gainesville, \\ FL 32611
}

\section{Thomas G. Beckman}

U.S. Department of Agriculture, Agricultural Research Service, Southeastern

Fruit and Tree Nut Research Laboratory, 21 Dunbar Road, Byron, GA 31008

\section{Additional index words. Prunus persica, resistance, root-knot nematode}

\begin{abstract}
Six commonly known peach rootstocks (i.e., Flordaguard, Guardian ${ }^{\circledR}$, Halford, Lovell, Nemaguard, and Okinawa) were evaluated for their susceptibility to Meloidogyne mayaguensis in the greenhouse. All rootstocks were rated as either nonhosts (highly resistant) or poor hosts (resistant) of $M$. mayaguensis. Lovell generally supported greater numbers of $M$. mayaguensis eggs per plant and eggs per gram of dry root, whereas no nematode reproduction was noted on Flordaguard rootstock (nonhost). Root galling occurred on all six rootstocks. However, reproduction as measured by number of egg masses, eggs per plant, and eggs per gram of dry root was a better measure of host resistance than number of root galls per plant.
\end{abstract}

Root-knot nematodes (Meloidogyne spp.) are an important pathogen of peach [Prunus persica (L.) Batsch] in the United States. The three major Meloidogyne spp. [M. arenaria (Neal) Chitwood, M. incognita (Kofoid \& White) Chitwood, and M. javanica (Treub) Chitwood] have been reported to cause damage to stone fruits in different parts of the world, but $M$. incognita and $M$. javanica are the predominant species reported on peach and plum. In a survey of South Carolina peach orchards, M. incognita and M. javanica were found in $95 \%$ and $5 \%$ of orchards sampled, respectively (Nyczepir et al., 1997). The Northern root-knot nematode, M. hapla Chitwood, develops poorly on Prunus spp. (Esmenjaud et al., 1994).

Meloidogyne mayaguensis Rammah and Hirschmann was originally obtained from galled roots of eggplant (Solanum melongena L.) from Puerto Rico in 1988 (Rammah and Hirschmann, 1988). In 2001, M. mayaguensis was detected in the continental United States

\footnotetext{
Received for publication 4 Dec. 2007. Accepted for publication 16 Jan. 2008.

We thank Merry A. Bacon and William T. Taylor, Jr., for technical assistance. We also acknowledge Mr. Billy Mills (Univ. of Georgia) and Dr. Jose Chaparro (Univ. of Florida) for providing the Flordaguard peach seed and Dr. Wayne Sherman (Univ. of Florida) the Okinawa peach seed used in this work.

${ }^{1}$ To whom reprint requests should be addressed; e-mail Andy.Nyczepir@ars.usda.gov
}

for the first time from samples collected from ornamental nurseries in South Florida (Brito et al., 2004). This highly virulent nematode pathogen is of concern to Florida's agricultural industry, because M. mayaguensis has been previously reported in West Africa to cause severe damage on root-knot nematoderesistant soybean 'Forrest' and sweetpotato 'CDH' cultivars (Fargette, 1987; Fargette et al., 1996) and on tomato 'Rossol', which contains the Mi-1 nematode resistance gene (Prot, 1984). Brito et al. (2004) has since confirmed that $M$. mayaguensis isolates from Florida can also reproduce on tomato containing the Mi-1 resistance gene. In south Florida, $M$. mayaguensis is known to be well established and to parasitize a number of different agricultural crops, including tropical fruit trees (Anon., 2003; Brito et al., 2004), demonstrating its polyphagous parasitic nature.

Concern with $M$. mayaguensis has arisen because of the increased interest in growing peaches in south and central Florida over the last 2 to 3 years. This renewed interest in growing peaches is the result of the release of new low-chill varieties developed at the University of Florida in Gainesville and because citrus growers are looking for an alternative crop to grow in place of citrus. In recent years, the Florida citrus industry has lost millions of trees to citrus canker (Xanthomonas axonopodis pv. citri) and is now encountering the more problematic bacteria disease known as citrus greening (Liberibacter asiaticus) (Layden, 2006). Growing peaches in a $M$. mayaguensis-infested site may present a potential problem when trying to establish a new peach orchard, especially if peach is a good host to this new nematode pathogen in Florida. Root-knot nematodes can cause stunted growth, loss of vigor, and early defoliation of 1- to 2-year-old peach trees when recommended management practices are not followed. Furthermore, root-knot nematodes typically do more damage to peach trees grown in sandy soils, common in Florida, than in fine-textured soils found elsewhere in the southeastern United States.

The current preplant nematicide recommendations for managing Meloidogyne sp. in peach in the southeastern United States include the soil fumigants, 1,3-D (1,3-dichloropropene) and Vapam (metam sodium) (Horton et al., 2007). These are the only two soil fumigants available to peach growers since the recent ban (according to the 1992 Montreal Protocol) on methyl bromide's importation and manufacture in the United States and western Europe in Jan. 2005 (Clean Air Act, 1990). As a result of pre- and postplant nematicides being removed from the agricultural market, alternatives to chemical control methods are being investigated (i.e., rootstock resistance) (Batchelor, 2002).

In the Southeast, Guardian ${ }^{\circledR}$ peach rootstock is recommended over Nemaguard as the rootstock of choice, because trees on Guard$\operatorname{ian}{ }^{\circledR}$ rootstock have exhibited resistance/tolerance to select isolates of Meloidogyne spp. and have a higher survival rate on peach tree short life sites than Nemaguard (Nyczepir et al., 1999, 2006; Okie et al., 1994). Peach rootstock susceptibility to $M$. mayaguensis is unknown. The objective of this research was to evaluate the host susceptibility of common peach rootstocks to $M$. mayaguensis.

\section{Materials and Methods}

Inoculum source and production. A population of $M$. mayaguensis (isolate N01-00304), originally isolated from an unidentified ornamental plant in Florida, and M. incognita isolated from peach in Georgia were both maintained on tomato (Solanum esculentum Mill. cv. Rutgers) in the greenhouse. Root-knot nematode egg inoculum was extracted from tomato roots using $\mathrm{NaOCl}$ solution (Hussey and Barker, 1973).

Host susceptibility. The experiment was conducted in an air-conditioned greenhouse at the USDA-ARS, Southeastern Fruit \& Tree Nut Research Laboratory in Byron, GA. Greenhouse facilities were in compliance with APHIS standards in evaluating M. mayaguensis. Nine-day-old Flordaguard, Guardian $^{\circledR}$ (i.e., advanced line SC 3-17-7), Halford, Lovell, and Nemaguard peach seedlings or 2-week-old 'Rutgers' tomato were planted in $10-\mathrm{cm}$ diameter plastic pots containing $\approx 450 \mathrm{~cm}^{3}$ sand-vermiculite medium (50:50 by volume). These particular peach rootstocks were evaluated in this study because of their known host reaction to some of the more common Meloidogyne spp. found 
in the Southeast and are summarized in Table 1 (Nyczepir and Beckman, 2000; Nyczepir et al., 1999, 2006; Nyczepir and Esmenjaud, 2007; Nyczepir and Halbrendt, 1993). Tomato was included because it is a known susceptible host to $M$. mayaguensis and to ascertain inoculum viability. Five days later (22 Mar. 2006), plants were inoculated with $\approx 3000$ M. mayaguensis eggs $/ 450 \mathrm{~cm}^{3}$ of medium. Approximately 1500 eggs were pipetted directly into each of two holes $(2.5 \mathrm{~cm}$ deep), one on either side of the plant stem. The holes were covered and additional water applied to settle the potting medium around the eggs. Treatments were replicated 10 times in a randomized complete block design on benches in the greenhouse.

Included within the same greenhouse were Nemaguard (known to be resistant) and Lovell (known to be susceptible) peach seedlings inoculated with $M$. incognita eggs. Meloidogyne incognita was included to confirm host resistance/susceptibility reaction by a known peach nematode pathogen. Two replications each of 'Rutgers' tomato were inoculated with $M$. incognita eggs to determine inoculum viability.

Peach seedlings were watered daily and fertilized as needed with Osmocote $(14 \mathrm{~N}-14 \mathrm{P}-14 \mathrm{~K})$. The greenhouse tempera-

Table 1. Reaction of peach rootstocks to root-knot nematode (Meloidogyne spp.). ${ }^{\mathrm{z}}$

\begin{tabular}{lllll}
\hline & \multicolumn{4}{c}{ Nematode $^{\mathrm{y}}$} \\
\cline { 2 - 5 } Rootstock & $\mathrm{Ma}$ & $\mathrm{Mi}$ & $\mathrm{Mj}$ & $\mathrm{Mf}$ \\
\hline Flordaguard & $-{ }^{\mathrm{x}}$ & $\mathrm{R}$ & - & $\mathrm{R}^{\mathrm{w}}$ \\
Guardian $^{\circledR}$ & - & $\mathrm{R}$ & $\mathrm{R} / \mathrm{S}$ & $\mathrm{S}$ \\
Halford $_{\text {Lovell }}^{-}$ & $\mathrm{S}$ & $\mathrm{S}^{\mathrm{v}}$ & - & - \\
Nemaguard & $\mathrm{R}$ & $\mathrm{S}$ & $\mathrm{S}$ & $\mathrm{S}$ \\
Okinawa & $\mathrm{R}$ & $\mathrm{R}$ & $\mathrm{R} / \mathrm{S}$ & $\mathrm{S}$ \\
\hline
\end{tabular}

${ }^{2}$ Nyczepir and Beckman, 2000; Nyczepir et al., 1999, 2006; Nyczepir and Esmenjaud, 2007; Nyczepir and Halbrendt, 1993.

${ }^{\mathrm{y}} \mathrm{Ma}=$ Meloidogyne arenaria $; \mathrm{Mi}=M$. incognita $\mathrm{Mj}=M$. javanica $; \mathrm{Mf}=M$. floridensis .

$\mathrm{x}_{-}=$unknown reaction.

${ }^{\text {w}}$ Host reaction: $\mathrm{R}=$ resistance; $\mathrm{S}=$ susceptible.

${ }^{v}$ A. P. Nyczepir, personal communication. tures ranged from 21 to $37{ }^{\circ} \mathrm{C}$. The study was ended after 114 d (14 July 2006) and the following data were collected: number of egg masses per root system, number of eggs per root system, number of root galls per root system, and dry root weight (dried at $70{ }^{\circ} \mathrm{C}$ in aluminum foil until no more loss in weight occurred). Root systems were also rated for number of egg masses produced (Taylor and Sasser, 1978). The egg mass index consisted of a 0 to 5 scale with $0=$ no egg masses, 1 = one to two egg masses, 2 = three to 10 egg masses, $3=11$ to 30 egg masses, $4=31$ to 100 egg masses, and $5=$ more than 100 egg masses. Host susceptibility was determined according to the egg mass index rating scale as follows: $0=$ nonhost (highly resistant), 1 to $2=$ a poor host (resistant), and $\geq 3=$ a good host (susceptible). The test was repeated once. Modifications were made in the second test that included inoculation of 12-day-old peach seedlings with $1000 \mathrm{M}$. mayaguensis or M. incognita eggs $/ 450 \mathrm{~cm}^{3}$ of medium and the addition of Okinawa peach rootstock; the study was ended after $115 \mathrm{~d}$ after inoculation (i.e., 20 Mar. 2007 to 13 July 2007).

Data were subjected to analysis of variance with the general linear models procedure of SAS (SAS Institute, Cary, NC). For the $M$. mayaguensis tests, appropriate preplanned single degree-of-freedom comparisons were then used to detect differences between treatment means for 'Rutgers' tomato versus combined peach rootstock means following a significant $F$ test. Means within peach rootstocks were analyzed using Fisher's protected least significant difference test. For $M$. incognita tests, analysis of variance was performed to determine rootstock effect on nematode reproduction and root galling. Only significant differences $(P \leq 0.05)$ are discussed unless stated otherwise.

\section{Results and Discussion}

'Rutgers' tomato (known susceptible) supported greater reproduction of M. maya- guensis than all peach cultivars combined as indicated by number of egg masses per plant, number of eggs per plant, and number of eggs per gram of dry root (Table 2). Individual rootstocks would either be rated as highly resistant (nonhost) or resistant (poor host) to $M$. mayaguensis infection based on the number of egg masses recovered (zero to three egg masses), although some rootstocks supported limited reproduction. Lovell (known susceptible to $M$. incognita) generally supported greater reproduction of $M$. mayaguensis than Nemaguard, Guardian ${ }^{\circledR}$, and Flordaguard as indicated by number of egg masses per plant, number of eggs per plant, and number of eggs per gram of dry root in most of the tests $(P \leq 0.05)$ (Table 2$)$. Although differences among Lovell, Nemaguard, Guardian $^{\circledR}$, and Flordaguard rootstocks were not significant $(P>0.05)$ for number of eggs per plant and eggs per gram of dry root in test 2 , greater numbers of eggs per plant and eggs per gram of dry root were detected on Lovell roots than on the other three stocks as observed in test 1. Also, Flordaguard was the only rootstock that did not support $M$. mayaguensis reproduction in both tests. This is of particular interest to the Florida peach industry because Flordaguard is also known to be resistant/tolerant to $M$. floridensis (Nyczepir et al., 2006; Sherman et al., 1991), a root-knot nematode that is known to attack Nemaguard rootstock.

Evaluating peach rootstocks for nematode resistance under greenhouse conditions can be challenging. It can be argued that greenhouse results may not provide a reliable prediction of performance as under field conditions. However, if the appropriate control treatment(s) is included within the greenhouse experiment and results substantiate those of previous reports, then one would have to consider the greenhouse data credible.

Lovell (known to be susceptible) supported greater reproduction of $M$. incognita than Nemaguard (known to be resistant) as indicated by number of egg masses per plant, number of eggs per plant, and number

Table 2. Susceptibility of selected peach and tomato cultivars to Meloidogyne mayaguensis and (or) M. incognita grown in the greenhouse after 114 (test 1 ) and $115 \mathrm{~d}$ (test 2$)$, respectively $(\mathrm{n}=10)^{2}{ }^{2}$

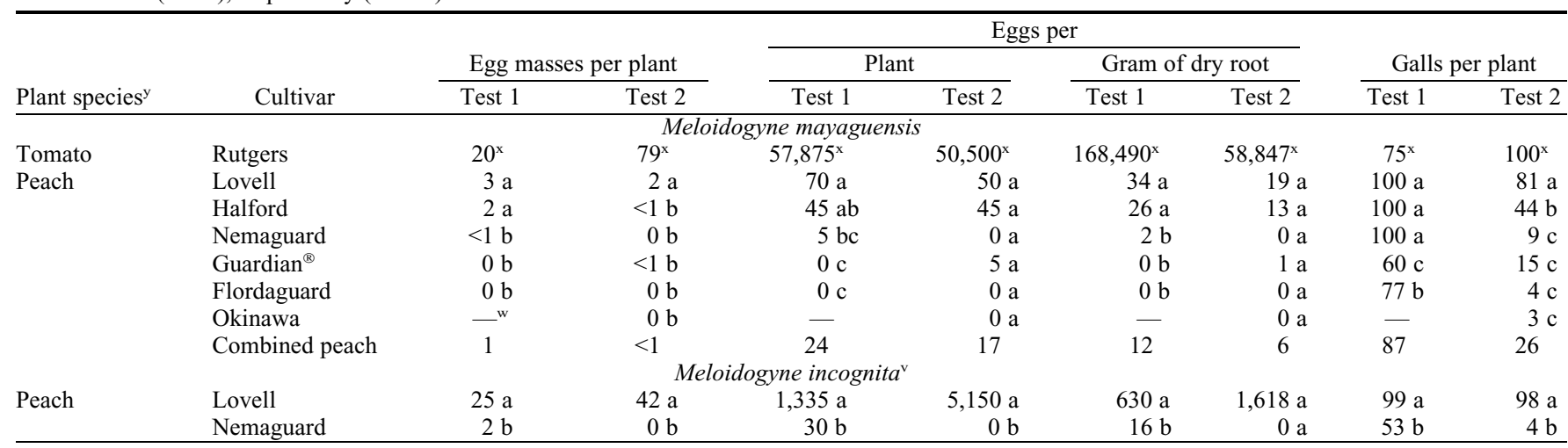

${ }^{\mathrm{Z}}$ Initial population density of Meloidogyne mayaguensis (FL_N0100304-isolate) and M. incognita (GA peach-isolate) in tests 1 and 2 was 3000 and 1000 eggs/450 $\mathrm{cm}^{3}$ sand-vermiculite medium, respectively.

${ }^{y}$ Means within a plant species and column followed by the same letter are not different by least significant difference $(P \leq 0.05)$.

${ }^{\mathrm{x}}$ The single degree-of-freedom comparison between the means for tomato versus combined peach cultivars was highly significant $(P \leq 0.05)$.

w_ $=$ not included.

${ }^{\vee}$ Mean separation within columns followed by the same letter are not different by analysis of variance $(P \leq 0.05)$. 
of eggs per gram of dry root in the two experiments $(P \leq 0.05)$ (Table 2$)$. Although differences between the two rootstocks were not significant $(P>0.05)$ for number of eggs per gram of dry root in test 2 , greater numbers of eggs per gram of dry root were detected on Lovell roots than on Nemaguard as observed in test 1 . The host reaction of Lovell versus Nemaguard rootstock to $M$. incognita in the current tests substantiates previous reports (Nyczepir et al., 1999; Nyczepir and Halbrendt, 1993) indicating that the two rootstocks and $M$. incognita are reliable control treatments under the current greenhouse conditions when evaluating rootstock reaction to $M$. mayaguensis. Reproduction on tomato by $M$. incognita as measured by eggs per plant was 16,250 (test 1) and 28,125 (test 2 ), thus indicating viable nematode inoculum. It is also important to note that gall formation in Nemaguard roots parasitized by $M$. incognita was more abundant (i.e., 13 -fold greater) in test 1 than test 2 . Nemaguard is generally resistant to this peach nematode pathogen; however, Brooks and Olmo (1961) noted that $25 \%$ of Nemaguard seedlings exhibited some root galling by $M$. incognita. It was later determined that Nemaguard segregates in a ratio of 3 immune to 1 susceptible (Sharpe et al., 1969) partially explaining gall formation on this rootstock. Another possible explanation for increased root galling in test 1 versus test 2 may be the result of differences in soil temperature. It has been reported that more root galls were produced by $M$. incognita in soil temperatures at $30^{\circ} \mathrm{C}$ than $25^{\circ} \mathrm{C}$ (Wehunt, 1972). It is thought that possibly the mechanism for nematode resistance in Nemaguard is compromised at the higher temperatures. Although daily ambient temperatures were not recorded during the entire experiment, it was noted that the ambient temperatures ranged from 21 to $35^{\circ} \mathrm{C}$, which may have been high enough to allow root gall formation in Nemaguard. It is interesting to note that a similar phenomenon in root galling caused by $M$. mayaguensis was observed in Lovell, Halford, Nemaguard, Guardian ${ }^{\circledR}$, and Flordaguard in test 1 versus test 2 . It is also interesting to note that although $M$. mayaguensis produced root galls on Nemaguard, Guardian $^{\circledR}$, Flordaguard, and Okinawa, the galls were generally associated with low or undetectable numbers of egg masses, eggs per plant, and (or) eggs per gram of dry root. One possible explanation for increased root galling, but no or low reproduction, may be the result of the inhibition of nematode development and failure of the majority of nematodes to complete the life cycle. Such a phenomenon was previously reported for $M$. javanica and $M$. incognita on Nemaguard and Guardian ${ }^{\circledR}$ peach, respectively (Meyer, 1977, 1978; Nyczepir et al., 1999). Reproduction as measured by number of egg masses and eggs per plant and eggs per gram of dry root was a better measure of host resistance than number of root galls per plant. Peach appears to be a poor host to M. mayaguensis; however, additional longterm field studies are needed to evaluate the effect of different $M$. mayaguensis isolates on growth of Flordaguard in various locations throughout Florida.

\section{Literature Cited}

Anon. 2003. Institute of Food and Agricultural Sciences State of Florida. New species of rootknot nematode. Cooperative Extension Service. South Florida Vegetable Pest and Disease Hotline. 31 Jan. 2003. <http://hchort.ifas.ufl.edu/ PDH1312003.html>.

Batchelor, T.A. 2002. International and European community controls on methyl bromide \& the status of methyl bromide use and alternatives in the European Community, p. 28-32. In: T.A. Batchelor and J.M. Bolivar (eds). Proc. Intl. Conf. Alter. Methyl Bromide 'The Remaining Challenges.' European Commission, Brussels, Belgium.

Brito, J., T.O. Powers, P.G. Mullin, R.N. Inserra, and D.W. Dickson. 2004. Morphological and molecular characterization of Meloidogyne mayaguensis isolates from Florida. J. Nematol. 36:232-240.

Brooks, R.M. and H.P. Olmo. 1961. Register of new fruit and nut varieties. Nemaguard peach. Proc. Amer. Soc. Hort. Sci. 78:634-635.

Clean Air Act. 1990. Title VI. Stratospheric ozone protection publication L. Section 6001, p. 101549. U.S. Congress, Washington, DC.

Esmenjaud, D., J.C. Minot, R. Voisin, J. Pinochet, and G. Salesses. 1994. Inter- and intraspecific resistance variability in Myrobalan plum, peach and peach-almond rootstocks using 22 root-knot nematode populations. J. Amer. Soc. Hort. Sci. 119:94-100.

Fargette, M. 1987. Use of esterase phenotype in the taxonomy of the genus Meloidogyne. 2. Esterase phenotypes observed in West African populations and their characterization. Revue de Nématologie 10:45-56.

Fargette, M., M.S. Phillips, V.C. Blok, R. Waugh, and D.L. Trudgill. 1996. An RFLP study of relationships between species, populations and resistance-breaking lines of tropical species of Meloidogyne. Fundam. Appl. Nematol. 19:193-200.

Horton, D., P. Brannen, B. Bellinger, and D. Ritchie. 2007. 2007 Southeastern peach, nectarine and plum pest management and culture guide. Univ. of Georgia Coop. Ext. Serv. Bull. \#1171.

Hussey, R.S. and K.R. Barker. 1973. A comparison of methods of collecting inocula of Meloido- gyne spp., including a new technique. Plant Dis. Rep. 57:1025-1028.

Layden, L. 2006. Peaches and green. Naples Daily News. 24 Apr. 2006. <http://www.naplesnews. com/news/2006/apr/24/peaches_and_green/>.

Meyer, A.J. 1977. Penetration of peach cultivars 'Kakamas' en 'Nemaguard' by the larvae of the root-knot nematode Meloidogyne javanica. Phytophylactica 9:73-74.

Meyer, A.J. 1978. Why is 'Nemaguard' rootstock resistant to root-knot nematodes (Meloidogyne spp.) and 'Kakamas' susceptible? Deciduous Fruit Grower 28:66-72.

Nyczepir, A.P. and T.G. Beckman. 2000. Host status of Guardian peach rootstock to Meloidogyne sp. and M. javanica. HortScience 35:772.

Nyczepir, A.P., T.G. Beckman, and G.L. Reighard. 1999. Reproduction and development of Meloidogyne incognita and $M$. javanica on Guardian peach rootstock. J. Nematol. 31: 334-340.

Nyczepir, A.P., T.G. Beckman, and G.L. Reighard. 2006. Field evaluation of Guardian peach rootstock to different root-knot nematode species. Acta Hort. 713:303-309.

Nyczepir, A.P. and D. Esmenjaud. 2007. Nematodes. In: Layne, D.R. and D. Bassi (eds.). The peach. CABI, Wallingford, Oxon, UK.

Nyczepir, A.P. and J.M. Halbrendt. 1993. Nematode pests of deciduous fruit and nut trees, $\mathrm{p}$. 381-425. In: Evans, K., D.L. Trudgill, and J.M. Webster (eds.). Plant parasitic nematodes in temperate agriculture. CABI, Wallingford, Oxon, UK.

Nyczepir, A.P., R.W. Miller, and T.G. Beckman. 1997. Root-knot nematodes on peach in the southeastern United States: An update and advances. Afr. Plant Prot. 3:115.

Okie, W.R., G.L. Reighard, T.G. Beckman, A.P. Nyczepir, C.C. Reilly, E.I. Zehr, and W.C. Newall, Jr. 1994. Field-screening Prunus for longevity in the southeastern United States. HortScience 29:673-677.

Prot, J.C. 1984. A naturally occurring resistancebreaking biotype of Meloidogyne arenaria on tomato. Reproduction and pathogenicity on tomato cultivars Roma and Rossol. Revue de Nématologie 7:23-28.

Rammah, A. and H. Hirschmann. 1988. Meloidogyne mayaguensis n. sp. (Meloidogynidae), a root-knot nematode from Puerto Rico. J. Nematol. 20:58-69.

Sharpe, R.H., C.O. Hesse, B.F. Lownsbery, V.G. Perry, and C.J. Hansen. 1969. Breeding peaches for root-knot nematode resistance. J. Amer. Soc. Hort. Sci. 94:209-212.

Sherman, W.B., P.M. Lyrene, and R.H. Sharpe. 1991. Flordaguard peach rootstock. HortScience 26:427-428

Taylor, A.L. and J.N. Sasser. 1978. Biology, identification, and control of root-knot nematode (Meloidogyne species). North Carolina State University Graphics, Raleigh, NC.

Wehunt, E.J. 1972. Influence of temperature on infection of Meloidogyne incognita acrita on 'Nemaguard' peach seedlings. Plant Dis. Rep. 56:305-308. 